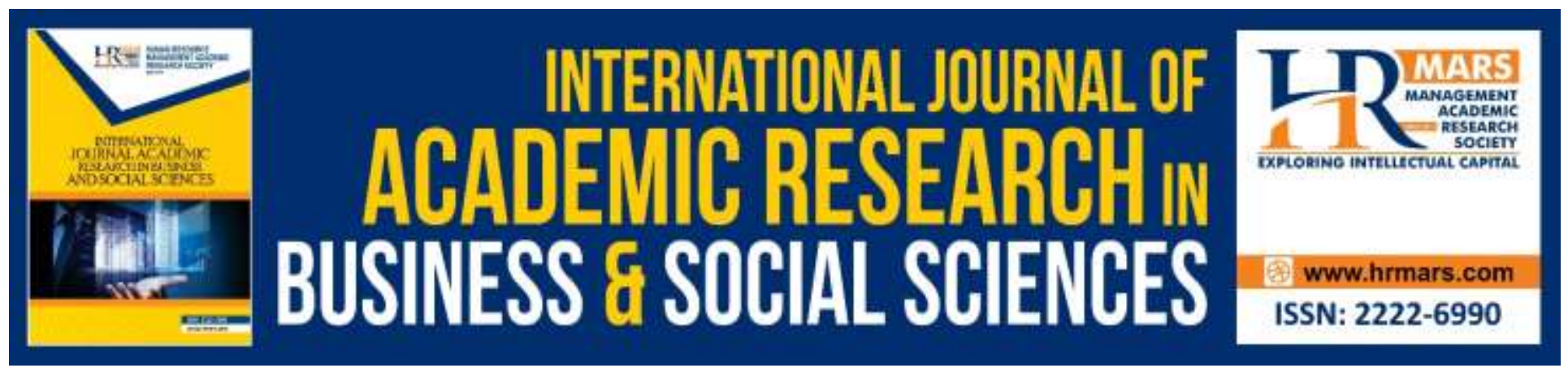

\title{
Agricultural Funding-Based Contributions and Performance of Nigerian Agricultural Sector
}

\section{Peter Chika Uzomba, Tarila Nikade and Oghenefejiro Praise Otokutu}

To Link this Article: http://dx.doi.org/10.6007/IJARBSS/v10-i1/6854

DOI:10.6007/IJARBSS/v10-i1/6854

Received: 23 December 2019, Revised: 10 January 2020, Accepted: 23 January 2020

Published Online: 30 January 2020

In-Text Citation: (Uzomba et al., 2020)

To Cite this Article: Uzomba, P. C., Peter Chika Uzomba, T. N., \& Otokutu, O. P. (2020). Agricultural FundingBased Contributions and Performance of Nigerian Agricultural Sector. International Journal of Academic Research in Business and Social Sciences, 10(1), 331-349.

Copyright: (c) 2020 The Author(s)

Published by Human Resource Management Academic Research Society (www.hrmars.com)

This article is published under the Creative Commons Attribution (CC BY 4.0) license. Anyone may reproduce, distribute, translate and create derivative works of this article (for both commercial and non-commercial purposes), subject to full attribution to the original publication and authors. The full terms of this license may be seen at: http://creativecommons.org/licences/by/4.0/legalcode

Vol. 10, No. 1, 2020, Pg. 331 - 349

http://hrmars.com/index.php/pages/detail/IJARBSS

JOURNAL HOMEPAGE

Full Terms \& Conditions of access and use can be found at http://hrmars.com/index.php/pages/detail/publication-ethics 


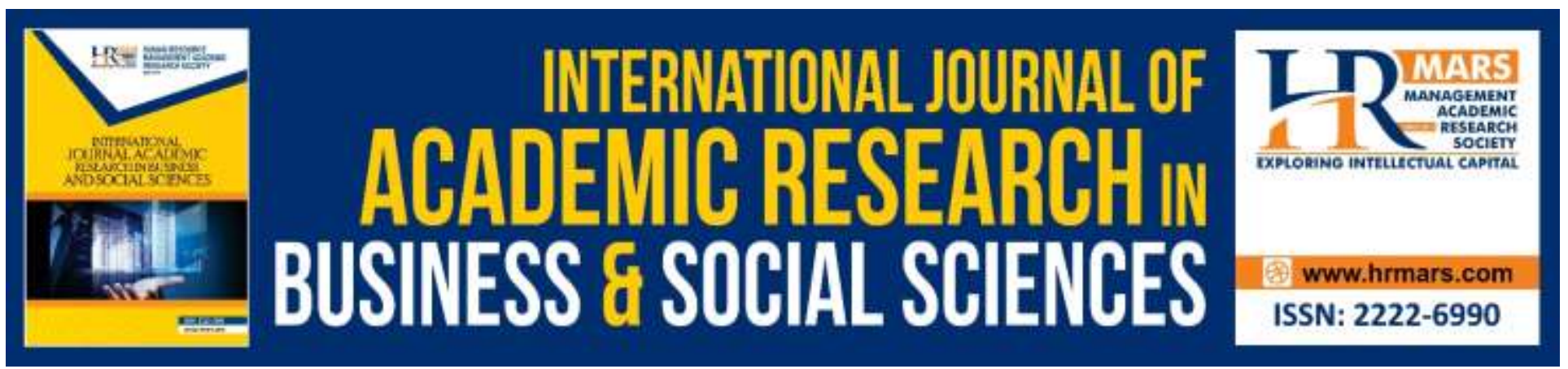

\title{
Agricultural Funding-Based Contributions and Performance of Nigerian Agricultural Sector
}

\author{
${ }^{1}$ Peter Chika Uzomba, ${ }^{2}$ Tarila Nikade and ${ }^{3}$ Oghenefejiro Praise \\ Otokutu \\ 1. Department of Economics, Federal University Lokoja, Kogi State, Nigeria, ${ }^{2,3}$ Department of \\ Economics, Edwin Clark University, Delta State, Nigeria. \\ Email: puzomba@yahoo.com, uzombapc@gmail.com
}

\begin{abstract}
On the account of assessing the performance of the Nigerian agricultural sector, this study puts in focus the relationship between agricultural funding-based contributions and performance of the Nigerian agricultural sector from 1986 to 2018, following the prescription of financial intermediation theory. It relies on ex-post facto research design, employs and makes use of data from the statistical bulletin of Central Bank of Nigeria, 2018 and Work Bank Economic Outlook 2019. Total government expenditure (TGE), agricultural credits (ACG) and foreign direct investment (FDI) serve as the independent variables; while crop production (CRP), livestock production (LSP), forestry production (FRP) and fishing production (FSP) represent the dependent variables. The study utilizes Jarque-Bera, Breush-Godfrey, Breush Pagan Godfrey, and Ramsey reset for normality tests, Augmented DickeyFuller (ADF) technique for stationarity test, Fully Modified Ordinary Least Square (FMOLS) and EngleGranger Single Equation Co-integration Tests for the search of possible link between the sets of variables. From the analyses, the results of the study reveal that TGE and AGS are significantly and positively related to CRP, LSP and FSP while FDI maintains a negative relationship with them. On another hand, TGE and FDI have negative relationship with FRP, but AGS is positively related to FRP. The Co-integration analysis reveals that there is a long run relationship between all the variables used in the four models. On this basis, the study concludes that agricultural funding-based contributions have significant and long run relationship with the performance of the Nigerian agricultural sector. The paper recommends that government should strengthen agricultural credit guarantee scheme and increase expenditures on the sector.
\end{abstract}

Keyword: Agriculture, Agricultural Components, Government Expenditure, Agricultural Credits, FDI.

\section{Introduction}

It is unarguable that agricultural sector makes actual and significant contributions to the Nigerian gross domestic product (GDP) profile. Economic literature makes an assertion that before the diversion of attention to the Nigerian oil sector, agricultural sector was the major contributor to the 
Nigerian economic growth. IFAD (2001) has it in good authority that it is the largest single employer and contributor to GDP in most of African countries. On a similar note, Ayeomoni and Aladejana (2016) argue that in Nigeria, agriculture is one of the most important sectors; in fact, about $80 \%$ of the population living in rural areas depends on agriculture for their livelihoods; also it provides employment for about $70 \%$ of the labor force, supplies raw materials to Nigeria's growing industries and serves as the main source of food for the teeming population. More importantly, the agricultural sector provides cash crops which constitute the most important source of revenue for most of the states of West Africa. During the pre and immediate post-independence era, the survival of the Nigerian economy was predicated on agriculture (Faluyi, 1996; Papapavlou \& Satraki, 2013). It contributed $90 \%$ of the nation's domestic production and foreign exchange earnings before oil was explored and exploited in commercial quantity in early 1970s (National Bureau of Statistics, 2014). Arising from the above stand point, the central role of agriculture cannot be overemphasized or underestimated in the economy of any nation, especially the developing ones (Oji-Okoro, 2011).

Every business venture, including the Nigerian agricultural sector, needs financial services for its optimal performance. In other words, agricultural financing constitutes the life-blood and central nerve of agri-business enterprise with which all other inputs would be procured (Mallum, 2016). Thus, a necessary condition for desired performance of the agricultural sector is largely adequate funding. This is because without adequate funding of the sector, it will be difficult for it to perform its traditional functions of feeding the populace, being the source of raw materials for industrial activities, and income generation for other developmental activities. Alluding to the importance of finance to the agricultural sector, Olomola (1997) has it that the provision of appropriate macroeconomic policies and enabling institutional finance for agricultural development is capable of facilitating agricultural development with a view to enhancing the contribution of the sector in the generation of employment, income and foreign exchange. Colman and Young (1989) maintain that funding-based contributions or investments play important roles in the process of agricultural development as it provides the opportunity to grow and expand the agricultural business, meet cash flow needs and ensure stable operations.

In recognition of the role of finance in agricultural performance, successive Nigerian governments have formulated and implemented several agricultural financial policies, programs and set up institutions with a view to ensuring availability of funds to agricultural sector and boost real activities that would lead to economic growth and development, encourage food production and better the lives of farmers (Ayeomoni \& Aladejana, 2016; Mallum, 2016; Ogbuabor \& Nwosu, 2017). Some of the policies and programs whose thrust was on providing finance for the improvement of the performance of the Nigerian agricultural sector include; National Centre for Agricultural Mechanisation (NCAM), Agricultural Credit Guarantee Scheme Fund (ACGSF), FADAMA I, II and III, River Basin Development Authorities (RBDAs), National Seed Service (NSS), Operation Feed the Nation (OFN), the farm settlement scheme, National Accelerated Food Production (NAFPP), the Nigerian Agricultural Cooperative And Rural Development Bank (NACRDB)/agricultural bank, Agricultural Development Projects (ADPs), Green Revolution Program, Directorate Of Foods, Roads And Rural Infrastructure (DFFRI), Nigerian agricultural insurance company (NAIC), National 
INTERNATIONAL JOURNAL OF ACADEMIC RESEARCH IN BUSINESS AND SOCIAL SCIENCES Vol. 10, No. 1, Jan, 2020, E-ISSN: 2222-6990 @ 2020 HRMARS

Agricultural Land Development Authority (NALDA), Specialized Universities for Agriculture, Root and Tuber Expansion Program (RTEP) and rural banking scheme (Iganiga and Unemghilin (2017). All these policies and programs were expected to drive the agricultural sector to an enviable height following an implied assumption that increased financing will encourage the performance of the sector in Nigeria.

In fact, Iganiga and Unemghilin (2017); Ariff, Kassim, Shoid, Abdullah, Baharuddin, Mansor, Radzi (2018) have gone ahead to report that Federal government capital expenditure was found to be positively related to agricultural performance in Nigeria with a policy import that finance is imperative to the performance of agricultural performance. Also, there is plenty of literature on agricultural financing in Nigeria (see for example; Okolo, 2004; Oboh, 2008; Onoja, Onu, \& AjodoOhiemi, 2012; Udoka, Mbat, \& Duke, 2016; Oparinde, Amos \& Adeseluka, 2017; Udeorah, \& Vincent 2018) who argue that provision of finance for agricultural sector ensures better performance of the sector. Iheanacho (2016) argues that recurrent expenditure is the major driver of economic growth and the variance decomposition confirms the collective contribution of public expenditure on economic growth, by implication the agricultural sector. Edewor, Dipeolu, Ashaolu, Akinbode, Ogbe, Edewor, Tolorunju, and Oladeji (2018) support this position that foreign direct investment and other selected variables contribute significantly to the performance of agricultural sector.

However, Iganiga and Unemghilin (2017) also argue that with observation of a one-year lag period, the impact of government finance on agriculture is not instantaneous. Following the aforementioned, one would expect that the performance of the Nigerian agricultural sector would sustainably lead in the contribution to GDP. However, it is obvious that the sector has disappointed this expectation. For instance, from 2010 to 2017, the agricultural sector contributed $\$ 13,048.99 b, \$ 13,429.30 b$, $\$ 14,329.71 b, \$ 14,750.52 b, \$ 15,380.39 b, \$ 15,952.22 b, \$ 16,607.34 b, \$ 17,179.50 b ;$ while the service sector surpassed this performance by contributing, within the same time frame, $\$ 10,966.58 \mathrm{~b}$,

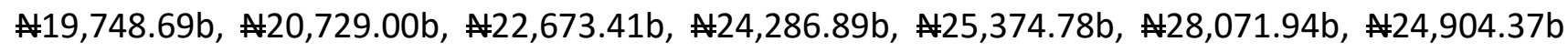
respectively (CBN, 2017).

Nevertheless, it is worthy of note that none of the above-mentioned studies was worried about the relationship between agricultural funding-based contributions and performance of the Nigerian agricultural sector. Hence this creates a gap in the body of extant literature. Arising from the foregoing, this question readily arouses and motivates the instinct of this study. Do agriculturalfunding based contributions through the mentioned policies and programs boost the performance of the agricultural sector in Nigeria? Responding to this question forms the crux of this study; thus this paper is motivated to contribute to the existing literature by examining the relationship between agricultural funding-based contributions and performance of the Nigerian agricultural sector; by individually considering how crop, livestock, forestry and fishing productions have performed, in relation to the financial contributions to the sector from 1986 and 2018. To achieve the objective mentioned above, the rest of the paper is sequenced in five (5) sections. The second section of this paper provides for literature review, on the basis of theoretical and empirical literature; while, the third looks at the research method of study, and empirical results and interpretations are the core 
INTERNATIONAL JOURNAL OF ACADEMIC RESEARCH IN BUSINESS AND SOCIAL SCIENCES

Vol. 10, No. 1, Jan, 2020, E-ISSN: 2222-6990 @ 2020 HRMARS

business of the fourth section; as discussion of results is treated in the fifth section and the conclusion and recommendations are presented in the sixth section.

\section{Literature Review}

The contributory impact of agricultural funding-based to the performance of the Nigerian agricultural sector has instigated research reports as documented in both theoretical and empirical space of extant literature. A good grasp of the causal link between agricultural financing and performance of agricultural sector will help in invoking specific policy measures with regards to how total government expenditure, provision of credit facilities; and foreign inflows would be properly managed to produce specific results in the Nigerian agricultural sector. In this direction, several theories underscore the relevance of the causal link between the contributions, otherwise expenditures, and performance of the sector. This paper relies on financial intermediation theory, which holds that finance is an imperative aspect that offers the opportunity for economic units to perform in most productive way. In other words, the theory is concerned with how finance relates to the economy on the whole, which the agricultural sector takes an integral part.

Thought by Schumpeter (1934) argues that a nation with a well-developed financial system would support economic growth. For him, it can be made possible by funds mobilization from different units to the lenders, farmers and agriculturalists alike at a lower cost of borrowing. While Schumpeter makes a strong case for financial intermediation as a necessary condition for economic growth, Greenwood and Jovanovich (1990); Bhilawa, Kautsar (2018) theorizes that rapid growth in any sector of an economy is premised on financial contributions in terms of government expenditure, and other investments directed to such a sector. Since agricultural sector is part of the anatomy of the Nigerian economy; it therefore implies that funding-based contributions to the sector would initiate, sustain and promote growth and ensure a higher rate of returns to be earned by the sector. This theory by implication suggests that providing financial contributions to agriculture through intermediation that captures government expenditures, agricultural credit guarantee scheme fund and foreign direct investment would make the sector perform as expected. Put differently, considerable increase in the performance of agricultural sector is premised on the effectiveness and efficient use of financial contributions to agricultural sector. This theoretical framework therefore suggests that the performance of the Nigerian agricultural sector is largely a function of agricultural funding-based contributions that the sector receives.

By way of reviewing empirical literature, scholars whose ideas have been documented Economic literature and allied disciplines have examined the performance of the Nigerian agricultural sector in relation to certain variables. To start with, Akintola (2004) used autocorrelation in conducting a study on the role of banking industry in financing agriculture and reported a responsive result. Ayoola and Oboh (2006) conducted a study to examine the outcome of agricultural production on economic growth. The findings showed that, if properly utilized, agricultural credit increases resource productivity, size of farm operations, encourages capital formation and diversified agriculture, innovations in farming, marketing efficiency, value added and net farm incomes, thereby resulting in economic growth. Evidence abound that the systemic decline in the performance of agriculture in 
Nigeria is due to insufficient funding-based contribution to the sector (see; Oboh, 2008). Ubah (2009) explored the impact of agricultural credit on agricultural output in Nigeria using an error correction model (ECM). The study found that agricultural credits have insignificant positive effect on agricultural output in Nigeria. Also, Oboh and Ekpebu (2010) examined the determinants of formal agricultural credit allocation to the farm sector using ordinary least square. They reported that to gain desirable result from the agricultural sector in Nigeria, a more effective and sustainable credit system is sacrosanct.

In a similar manner, Ammaini (2012) investigated the relationship between agricultural production and formal credit supply in Nigeria and reported that formal credit is positively and significantly related to the productivity of the crop, livestock forestry and fishing sectors. Government capital expenditure, loans from deposit money banks and credit facilities have been reported to have significant relationship between the Nigerian agricultural sector (see for example, Imoisi, Sogules \& Ekpeyoung, 2012; Onoja, 2012), agricultural financing in Nigeria is significantly related with the growth of Nigerian economy (Nwankwo, 2013; Chisasa and Makina, 2013), agricultural credit, government fund allocation and commercial banks' credit have significant positive effect on agricultural performance in Nigeria (Obilor, 2013), commercial bank and public sector financing activities are significant factor that influence agricultural productivity in Nigeria (Ibe, 2014; Baffoe, Matsuda, Nagao \& Akiyama, 2014; Nnamocha and Eke, 2015; Agunuwa, Inaya \& Proso, 2015; Olowofeso, Adeboye, Adejo, Bassey \& Abraham, 2017; Udeorah \& Vincent, 2018; Caroline, 2019).

The empirical literature shows that agricultural funding- based contributions are vital to the performance of the agricultural sector of any country. While the reviewed literature is vital to the current study, there is still a gap which this study intends to contribute in filling. Particularly, most of these studies focused on one aspect of agricultural financing - government expenditure and agricultural credits, aggregate of agricultural sector, had study periods less than 30 years, used conventional ordinary least squares methods, error correction mechanism of method, but failed to conduct diagnostic tests, used fully modified ordinary least squares and Engle-Granger Single Equation Co-integration Estimation. However, our study fills this gap by considering agricultural funding-based contributions in terms of -government expenditures, agricultural credits and foreign direct investments; and assesses the performance of agricultural sector by looking at individual components of the sector, in terms of crop production, livestock production, forestry production, and fishing production from 1986-2018. This is the main motivation of this study.

\section{Method of Study}

Empirical tests on economic variables have been carried out with different econometric methods. The method of study herein aims at empirically establishing the relationship between agricultural funding-based contributions and performance of the Nigerian agricultural sector from 1986 to 2018. For this purpose, ex-post facto research design was employed; secondary data from statistical bulletin of Central Bank of Nigeria 2018 and Work Bank Economic Outlook 2019 were sourced and utilized on total government expenditure (TGE), agricultural credit (ACG) and foreign direct investment (FDI) as independent variables. Crop production (CRP), livestock production (LSP), forestry production (FRP) 
and fishing production (FSP) were used as the dependent variables. The methodological procedures start with the definition, description and measurement of study variables, model specification, presentation and interpretation of empirical results of descriptive statistics, unit root, fully modified ordinary least square and Engle-Granger co-integration test.

Table 1: Description of study variables

\begin{tabular}{|c|c|c|c|}
\hline $\begin{array}{c}\text { Variabl } \\
\text { e }\end{array}$ & Definition and Description of Performance & $\begin{array}{l}\text { Measureme } \\
\text { nt }\end{array}$ & Source \\
\hline CRP & $\begin{array}{l}\text { This is the total output of crop farming in Nigeria. Its } \\
\text { performance is measured in terms of its contributions } \\
\text { to GDP }\end{array}$ & $\begin{array}{l}\text { It is } \\
\text { measured in } \\
\text { billion naira }\end{array}$ & $\begin{array}{l}\text { CBN } \\
\text { statistical } \\
\text { bulletin } \\
(2018)\end{array}$ \\
\hline LSP & $\begin{array}{l}\text { This is the total production of livestock farming in } \\
\text { Nigeria. Its performance is measured in terms of its } \\
\text { contributions to GDP }\end{array}$ & $\begin{array}{l}\text { It is } \\
\text { measured in } \\
\text { billion naira }\end{array}$ & $\begin{array}{l}\text { CBN } \\
\text { statistical } \\
\text { bulletin } \\
(2018)\end{array}$ \\
\hline FRP & $\begin{array}{l}\text { This is the total output of the forestry activities in } \\
\text { Nigeria. Its performance is measured in terms of its } \\
\text { contributions to GDP }\end{array}$ & $\begin{array}{l}\text { It is } \\
\text { measured in } \\
\text { billion naira }\end{array}$ & $\begin{array}{l}\text { CBN } \\
\text { statistical } \\
\text { bulletin } \\
(2018)\end{array}$ \\
\hline FSP & $\begin{array}{l}\text { This is the aggregated fishing production in Nigeria. Its } \\
\text { performance is measured in terms of its contributions } \\
\text { to GDP }\end{array}$ & $\begin{array}{l}\text { It is } \\
\text { measured in } \\
\text { billion naira }\end{array}$ & $\begin{array}{l}\text { CBN } \\
\text { statistical } \\
\text { bulletin } \\
(2018)\end{array}$ \\
\hline TGE & $\begin{array}{l}\text { This is the aggregation of recurrent and capital } \\
\text { government expenditures. }\end{array}$ & $\begin{array}{l}\text { It is } \\
\text { measured in } \\
\text { billion naira }\end{array}$ & $\begin{array}{l}\text { CBN } \\
\text { statistical } \\
\text { bulletin } \\
(2018)\end{array}$ \\
\hline ACG & $\begin{array}{l}\text { This is defined as the total loans and advances } \\
\text { provided by the scheme to the Nigerian agricultural } \\
\text { sector. }\end{array}$ & $\begin{array}{l}\text { It is } \\
\text { measured in } \\
\text { million naira }\end{array}$ & $\begin{array}{l}\text { CBN } \\
\text { statistical } \\
\text { bulletin } \\
(2018)\end{array}$ \\
\hline FDI & $\begin{array}{l}\text { This is the value of direct investment made in Nigeria } \\
\text { by non-residents. }\end{array}$ & $\begin{array}{l}\text { It is } \\
\text { measured in } \\
\text { billion } \\
\text { dollars }\end{array}$ & $\begin{array}{l}\text { World Bank, } \\
2019\end{array}$ \\
\hline
\end{tabular}

Source: Authors' Complication, 2019.

Model Specification for Short Run Fully Modified Ordinary Least Squares 


\section{Crop Production (CRP) Model}

The model is specified in general functional form as:

$\mathrm{CRP}=\mathrm{f}(\mathrm{TGE}, \mathrm{ACG}, \mathrm{FDI})$

Stating the relationship in an econometric model gives;

$\mathrm{CRP}_{\mathrm{t}}=\beta_{0}+\beta_{1} \mathrm{TGE}_{\mathrm{t}}+\beta_{2} \mathrm{ACG}_{\mathrm{t}}+\beta_{3} \mathrm{FDI}_{\mathrm{t}}+\mu_{\mathrm{t}}$

The a-priori expectations are: $\beta_{0} \neq 0 ; \beta_{1}, \beta_{2}, \beta_{3},>0$

\section{Livestock Production (LSP) Model}

The model is specified in general functional form as:

$L S P=f(T G E, A C G, F D I)$

Stating the relationship in an econometric model gives;

$\mathrm{LSP}_{\mathrm{t}}=\mathrm{L}_{0}+\mathrm{L}_{1} \mathrm{TGE}_{\mathrm{t}}+\mathrm{L}_{2} \mathrm{ACGt}+\mathrm{L}_{3} \mathrm{FDI}_{\mathrm{t}}+\mu_{\mathrm{t}}$

The a-priori expectations are: $L_{0} \neq 0 ; L_{1}, L_{2}, L_{3},>0$

\section{Forestry Production (FRP) Model}

The model is specified in general functional form as:

$F O P=f(T G E, A C G, F D I)$

Stating the relationship in an econometric model gives;

$F O R_{t}=f_{0}+f_{1} T_{G E}+f_{2} A C G_{t}+f_{3} F D I_{t}+\mu_{t}$

The a-priori expectations are: $f_{0} \neq 0 ; f_{1}, f_{2}, f_{3},>0$

\section{Fishing Production (FSP) Model}

The model is specified in general functional form as:

$F I P=f(T G E, A C G, F D I)$

Stating the relationship in an econometric model gives;

$\mathrm{FIP}_{\mathrm{t}}=P_{0}+P_{1} \mathrm{TGE}_{\mathrm{t}}+P_{2} \mathrm{ACG}_{\mathrm{t}}+P_{3} \mathrm{FDI}_{\mathrm{t}}+\mu_{\mathrm{t}}$

The a-priori expectations are: $P_{0} \neq 0 ; P_{1}, P_{2}, P_{3},>0$

$\beta_{0}, L_{0}, f_{0}$, and $P_{0}=$ Intercepts or slopes of the regression lines; they are assumed not to be zero (0).

$\beta_{1}, L_{1}, f_{1}$, and $P_{1}=$ coefficients of TGE to be estimated for the four econometric models.

$\beta_{2}, L_{2}, f_{2}$, and $P_{2}=$ coefficients of ACG to be estimated for the four econometric models.

$\beta_{3}, L_{3}, f_{3}$, and $P_{3}=$ coefficient of FDI to be estimated for the four econometrics models.

Following Gujarati and Sangeetha (2007), the study utilizes Augmented Dickey-Fuller (ADF) test technique for stationarity test for all the variables. The choice of ADF is informed by the fact in conducting unit root test using Dickey-Fuller (DF), it is assumed that the error term $u_{t}$ is uncorrelated. However, in a case the $u_{t}$ are correlated, DF technique becomes insufficient in testing the unit root of a variable in a model (see Gujarati \& Sangeetha, 2007). Consequently, our study conducts unit test for all the variables by augmenting the equations through addition of lagged values of the dependent variables, $\Delta Y_{t}$, to the explanatory variables. This is specified thus: 
$\Delta \mathrm{Y}_{\mathrm{t}}=B_{1}+b_{1} t+\delta \Delta \mathrm{Y}_{\mathrm{t}-1}+\sum \alpha_{\mathrm{i}} \Delta \mathrm{Y}_{\mathrm{t}-1}+\varepsilon_{t}$

In order to establish a fact that the data of the variables are normally distributed, certain diagnostic tests are conducted. Such tests include: the Jarque-Bera normality - test for a goodness-of-fit. This is used to test whether or not the sample data on a variable has the skewness and kurtosis matching a normal distribution. The null hypothesis for this test is that the data for the variables is normally distributed; while the alternate hypothesis says that the data fail to come from a normal distribution. Also, Breush-Godfrey serial correlation test is conducted. This was used to test for serial correlation or autocorrelation of the residuals or the errors in the four regression models (equations 2, 4, 6 and 8). Serial correlation or autocorrelation is a methodical or orderly pattern in the errors or residuals that can be either positive (attracting) or repelling (keeping the errors at bay). Breush Pagan Godfrey test is done to test for the evidence or presence of heteroscedasticity. As per the decision rule; if the test statistical value of each variable is below a chosen alpha level of $5 \%(0.05)$, then we fail to reject the null hypothesis of homoskedasticity, if otherwise, the heteroskedasiticity is assumed. Lastly, Ramsey reset test is conducted to test for the whether or not the functional form of the equation is properly specified. It also tests whether the fitted values help in the explanation of the response variable in focus. The null hypothesis of Ramsey reset test holds that if all coefficients are zero, then the null hypothesis is rejected; then the model suffers from misspecification; if otherwise, then the alternate is retained - suggesting that model does not suffer from misspecification.

It is worth noting that several methods could be used in a study of this magnitude. However, the issues of asymptotic efficiency may not be properly addressed by all short run methods, such as ordinary least squares. Hence this paper adopts Fully Modified Ordinary Least Square (FMOLS) estimation technique with multiple linear regression analytical approach. The efficiency and effectiveness of FMOLS lie on its ability to employ kernel estimators of the nuisance parameters that affect the asymptotic distribution of the OLS estimator (see, Aljebrin, 2012; Risso, et. al., 2013). Also, the asymptotic efficiency of FMOLE method modifies least squares to account for serial correlation that effect and test for the endogeneity in the regressors that result from the existence of a cointegrating relationship (also see Belke \& Czudaj, 2010; Aljebrin, 2012; Risso, et al., 2013). As Grander cited in Gujarati and Sangeetha (2007) notes, a test of cointegration can be thought of as a pre-test to avoid spurious regression situation. The co-integration test is to ascertain whether there is or otherwise, a long run relationship between the variables. Though a number of methods for testing cointegration have been proposed in the extant economic literature, this study relies on Engle-Granger Single Equation Co-integration Test which bridges the differential gap between DF and ADF. Hence, it is regarded as a superior test for co-integration as it has all desirable statistical properties. The analytical framework of this paper is within the orientation of quantitative approach which relies on Rhaji (2008), Ubah (2009), Obilor (2013), Enyim, Ewno and Okoro (2013) and Oparinde, Amos and Adeseluka (2017). Following the research direction of the studies mentioned above, the analytical framework of this present study relies on: $P A=f(A F B C)$. This means that the performance of an agricultural sector (PA) functionally depends on the funding-based contributions that go to the sector (AFBC). 


\section{Presentation of Empirical Results and Interpretation}

To formally establish the tenability of the normality of the variables, certain diagnostics tests were conducted and reported in table 2 below:

Table 2: Results of Diagnostic Tests for all the variables in the models

\begin{tabular}{|c|c|c|c|c|c|c|c|c|}
\hline \multirow{2}{*}{$\begin{array}{l}\text { Statistics } \\
\text { Features }\end{array}$} & \multicolumn{2}{|c|}{ CRP } & \multicolumn{2}{|c|}{ LSP } & \multicolumn{2}{|c|}{ FRP } & \multicolumn{2}{|c|}{ FSP } \\
\hline & $\begin{array}{c}\text { Statisti } \\
\text { cs }\end{array}$ & Prob. & $\begin{array}{c}\text { Statisti } \\
\text { CS }\end{array}$ & Prob. & $\begin{array}{c}\text { Statisti } \\
\text { CS }\end{array}$ & Prob. & $\begin{array}{c}\text { Statisti } \\
\text { CS }\end{array}$ & Prob. \\
\hline $\begin{array}{l}\text { Jarque-Bera } \\
\text { Normality Test }\end{array}$ & 0.3129 & $\begin{array}{l}0.855 \\
1\end{array}$ & $\begin{array}{l}114.70 \\
24\end{array}$ & $\begin{array}{l}0.000 \\
0\end{array}$ & 0.7281 & $\begin{array}{l}0.694 \\
8\end{array}$ & 0.8600 & $\begin{array}{l}0.650 \\
4\end{array}$ \\
\hline $\begin{array}{l}\text { Breush-Godfrey } \\
\text { Serial } \\
\text { Correlation LM } \\
\text { Test }\end{array}$ & 0.3510 & $\begin{array}{l}0.712 \\
3\end{array}$ & 0.8693 & $\begin{array}{l}0.432 \\
0\end{array}$ & 0.4487 & $\begin{array}{l}0.648 \\
7\end{array}$ & 8.5560 & $\begin{array}{l}0.097 \\
8\end{array}$ \\
\hline $\begin{array}{l}\text { Heteroskedastic } \\
\text { ity Test: Breush } \\
\text { Pagan Godfrey }\end{array}$ & 2.3236 & $\begin{array}{l}0.073 \\
8\end{array}$ & 0.7220 & $\begin{array}{l}0.584 \\
7\end{array}$ & 0.9427 & $\begin{array}{l}0.543 \\
1\end{array}$ & 0.6137 & $\begin{array}{l}0.819 \\
4\end{array}$ \\
\hline Ramsey RESET & 0.5878 & $\begin{array}{l}0.568 \\
5\end{array}$ & 0.7064 & $\begin{array}{l}0.486 \\
4\end{array}$ & 6.5351 & $\begin{array}{l}0.084 \\
9\end{array}$ & 0.0915 & $\begin{array}{l}0.929 \\
1\end{array}$ \\
\hline
\end{tabular}

Source; Authors' computation using E-views 9.0, 2019.

Four diagnostic tests are conducted to empirically establish the normality of the variables. The Jarque-Bera normality test results for all the variables were $0.8551,0.0000,0.6948$, and 0.6504 for CRP, LSP, FRP and FSP respectively. From the result, the values of CRP, FRP and FSP variables are greater than 5\%; while that of LST variable is less than $5 \%$. By implication, it is suggestive that the null hypotheses for CRP, FRP and FSP variables and models are normally distributed; while that of LSP variable does not come from a normal distribution. The result of Breush-Godfrey serial correlation test reveals that the variables - CRP, LSP, FRP and FSP have probability values of $0.7123,0.4320$, 0.6487 and 0.0978 respectively. Intuitively, it is evident that the values of the variables are greater than $5 \%$ significance level; then the null hypothesis of there is no serial correlations of any order up to $p$-value is rejected and the alternate is assumed. This means that there is the presence of autocorrelation; hence the need to conduct a unit root test to ensure the stability of the data of the variables. The results of Breush Pagan Godfrey test of the variables reveals that CRP, LSP, FRP and FSP have values of $0.07123,0.5847,0.5431$ and 0.8194 respectively. On this basis, it is informative to establish that all the values of the variables are greater the appropriate threshold of 0.05 , and therefore the null hypothesis of homoskedasticity is dropped and the heteroskedasticity is assumed. Similarly, the Ramsey reset results indicate that CRP, LSP, FRP and FSP variables have values of $0.5685,0.4864,0.0849$ and 0.9291 respectively. From every indication all the probability values are not zero; that is, they are greater than zero, then the null hypothesis that all the values are zero is 
INTERNATIONAL JOURNAL OF ACADEMIC RESEARCH IN BUSINESS AND SOCIAL SCIENCES Vol. 10, No. 1, Jan, 2020, E-ISSN: 2222-6990 C 2020 HRMARS

dropped and the alternate assumed. This implies that the four models of the equation do not suffer from misspecifications and the functional form is properly specified. Consequently, other inferential statistical tests are conducted.

\section{Presentation of Unit Root Results Analyzed with Augmented Dickey-Fuller Test (ADF)}

In order to ascertain whether time series data were stationary or non-stationary and also to determine the number of times (the level) at which the variables have to be differenced before becoming stationary, unit root tests are conducted.

Table 3: Result of Unit Root Test

\begin{tabular}{|c|c|c|c|c|}
\hline Variable & T-statistics & P-value & Stationaarity & $\begin{array}{l}\text { Order of } \\
\text { Integration }\end{array}$ \\
\hline LnCRP & -1.995340 & 0.5809 & NS & \\
\hline$\Delta \operatorname{lnCRP}$ & $-5.347932 *$ & 0.0008 & $S$ & I(1) \\
\hline LnLSP & 0.546149 & 0.9856 & NS & \\
\hline$\Delta \operatorname{lnLSP}$ & $-2.827903^{* *}$ & 0.0664 & $S$ & $\mathrm{I}(1)$ \\
\hline LnFRP & 2.077999 & 0.9891 & NS & \\
\hline$\Delta \operatorname{lnFRP}$ & $-4.816030 *$ & 0.0000 & $S$ & $\mathrm{I}(1)$ \\
\hline LnFSP & $-5.282491^{*}$ & 0.0009 & $S$ & $\mathrm{I}(0)$ \\
\hline LnACG & 1.010414 & 0.9137 & NS & \\
\hline$\triangle \ln A C G$ & $-2.848245^{*}$ & 0.0060 & $S$ & $\mathrm{I}(1)$ \\
\hline LnTGE & -1.124241 & 0.9078 & NS & \\
\hline$\Delta \operatorname{lnTGE}$ & $-9.544637^{*}$ & 0.0000 & $S$ & $\mathrm{I}(1)$ \\
\hline LnFDI & 0.872630 & 0.8928 & NS & \\
\hline$\Delta \operatorname{lnFDI}$ & $-9.642956^{*}$ & 0.0000 & $S$ & $\mathrm{I}(1)$ \\
\hline
\end{tabular}

Source: Authors' computation using E-Views 9.0, 2019.

$(*),(* *)$ and $\left({ }^{* * *}\right)$ denotes significant at $1 \%, 5 \%$ and $10 \%$ respectively. NS, $S$ and $I(1)$ indicate not stationary, stationary and integrated at order one respectively.

It is noteworthy to point out that all the values of each variable is in log-linearised form. A close look at the table reveals that all the variables, except the natural log of fishing equation - InFSP, was stationary at level while FSP was non stationary at level but at first difference. This is so because, at levels, the p-values of crop production (InCRP), livestock (InLSP), Forestry (InFRP), ACGSF (InACG), total government expenditure (InTGE) and foreign direct investment (InFDI) which are not less than the $1 \%, 5 \%$ or $10 \%$ significance value. After taking the first difference of the six variables, they become stationary at first difference and are regarded as I(1) serial order of integration. However, InFRP that is stationary at level, hence it is regarded as I(O) serial order of integration. Resulting from this, the variables are fit to be used for further analysis.

Table 4: Result of Fully Modified Least Square Regression for all the Estimated Models 
INTERNATIONAL JOURNAL OF ACADEMIC RESEARCH IN BUSINESS AND SOCIAL SCIENCES Vol. 10, No. 1, Jan, 2020, E-ISSN: 2222-6990 @ 2020 HRMARS

\begin{tabular}{|c|c|c|c|c|c|c|c|c|}
\hline \multirow[t]{2}{*}{ Variable } & \multicolumn{2}{|c|}{ CRP Model } & \multicolumn{2}{|c|}{ LSP Model } & \multicolumn{2}{|c|}{ FRP Model } & \multicolumn{2}{|c|}{ FSP Model } \\
\hline & $\begin{array}{c}\text { Coefficie } \\
\text { nt }\end{array}$ & Prob. & $\begin{array}{c}\text { Coefficie } \\
\text { nt }\end{array}$ & Prob. & $\begin{array}{c}\text { Coefficie } \\
\text { nt }\end{array}$ & Prob. & $\begin{array}{c}\text { Coefficie } \\
\text { nt }\end{array}$ & Prob. \\
\hline \multirow[t]{2}{*}{ LNTGE } & & 0.005 & & 0.191 & - & 0.700 & & \\
\hline & 0.097937 & 1 & 0.028707 & 3 & 0.014296 & 7 & 0.165586 & 0.0039 \\
\hline \multirow[t]{2}{*}{ LNACG } & & 0.000 & & 0.000 & & 0.000 & & \\
\hline & 0.265582 & 0 & 0.179801 & 0 & 0.204436 & 0 & 0.201616 & 0.0015 \\
\hline \multirow[t]{2}{*}{ LNFDI } & - & 0.776 & - & 0.126 & - & 0.055 & - & \\
\hline & 0.015088 & 1 & 0.055166 & 4 & 0.120207 & 6 & 0.100056 & 0.2531 \\
\hline \multirow[t]{2}{*}{ C } & & 0.000 & & 0.000 & & 0.000 & & \\
\hline & 4.728999 & 0 & 5.024003 & 0 & 4.506634 & 1 & 3.291626 & 0.0291 \\
\hline $\begin{array}{l}\text { R- } \\
\text { Squared } \\
\text { Values }\end{array}$ & 0.970733 & & 0.933220 & & 0.841942 & & 0.905008 & \\
\hline
\end{tabular}

Dependent Variables: LNCRP, LNLSP, LNFRP, LNFSP.

Source: Authors' computation using E-Views 9.0, 2019.

The coefficient of TGE shows that a percentage increase in total government expenditure causes 0.097939 percent increase in crop production (CP). A percentage increase in ACG increases crop production by 0.265582 percent, the coefficient of FDI shows that a percentage increase in foreign direct investment leads to a 0.015088 percent decrease in crop production. From the result, it is evident that the TGE and ACG have positive relationship with CRP, while FDI has negative relationship with CRP. The R-Squared $\left(R^{2}\right)$ shows a value of 0.970733 (approximately $97.1 \%$ ). This indicates that the independent variables TGE, ACG, FDI account for about $97.1 \%$ of the variations in the dependent variable - crop production (CRP), which makes the model fit enough to explain the subject matter, because it is closer to one (1).The remaining 2.93 accounts for the unexplained variables not captured in the model but contributed to other factors that could cause changes in crop production. Going further, the coefficient of TGE shows that a percentage increase in total government expenditure lead s to 0.028707 percent increase in livestock production (LSP). A percentage increase in ACG increases livestock output by 0.179801 percent, the coefficient of FDI shows that a percentage increase in foreign direct investment leads to a 0.055166 percent decrease in livestock production. The R-Squared $\left(R^{2}\right)$ shows a value of 0.933220 (approximately 93.3\%). This indicates that the independent variables - TGE, ACG, FDI, account for about $93.3 \%$ of the variations in the dependent variable LSP. The variation is caused by factors that affect LSP but were not captured in the model.

The coefficient of TGE shows that a percentage increase in total government expenditure will lead to 0.014296 percent decrease in FRP, a percentage increase in the ACG increases FRP by 0.204436 percent, but the coefficient of FDI shows that a percentage increase in FDI leads to a 0.120207 percent decrease in FRP. The R-Squared $\left(R^{2}\right)$ has a value of 0.841942 (approximately $84.19 \%$ ). This indicates that the independent variables TGE, ACG, FDI account for about $84.2 \%$ of the variations that occur in the dependent variable (FRP). This means that the regression estimation is good enough to examine the relationship between agricultural funding-based contributions and performance of the 
Nigeria agricultural sector. Since $84.2 \%$ change in FRP could be explained by TGE, ACG and FDI, the remaining $15.8 \%$ change is caused by factors that could affect FRP, but are not captured in the third model. The coefficient of TGE shows that a percentage increase in total government expenditure leads to 0.165586 percent increase in FSP. Also a percentage increase in ACG increases FSP by 0.201616 percent, however, the coefficient of FDI shows that a percentage increase in foreign direct investment leads to a 0.100056 percent decrease in FSP. The R-Squared $\left(R^{2}\right)$ has a value of 0.905008 (approximately 90.5\%). This implies that the independent variables TGE, ACG, FDI account for about 90.50\% of the variations in the dependent variable FSP. This suggests that the model could not explain the remaining $9.5 \%$ variations in the dependent variable. The probability values in the same table reveals that TGE and AGS are significant; while FDI is not significant. This is because the values of TGE and AGS are less than $5 \%$, but that of FDI is greater than $5 \%$ level of significance.

Table 5: Engle-Granger Single Equation Co-integration Test Result for Model I

\begin{tabular}{|c|c|c|c|c|}
\hline Variables & tau-statisti & Prob. ${ }^{*}$ & z-statistic & Prob.* \\
\hline LNCRP & -2.598221 & 0.6433 & -13.98534 & 0.4572 \\
\hline LNACG & -2.638388 & 0.6246 & -13.76069 & 0.4723 \\
\hline LNTGE & -2.197895 & 0.8092 & -7.327115 & 0.8835 \\
\hline LNFDI & -5.148686 & 0.0182 & 9.257634 & 1.0000 \\
\hline
\end{tabular}

Source: Authors' computation using E-views 9.0, 2019.

From the table above, it is evident that there is a long run relationship between all the variables in model 1 (CRP, ACG, TGE, FDI). Also, it has a result showing that at least FDI is significant at 5\%; since it has 0.0182 probability values at tau-statistics. This further reveals that there is a long run relationship among the variables, because there is evidence of one co-integrating equation in $t$ statistics.

Table 6: Engle-Granger Single Equation Co-integration Test Result for Model 2

\begin{tabular}{lccrc} 
Variables & \multicolumn{2}{c}{ Tau-statistic Prob.* } & z-Statistic & Prob. $^{*}$ \\
\hline LNLSP & 0.160705 & 0.9996 & 0.482146 & 0.9996 \\
LNTGE & -1.871680 & 0.9024 & -5.708511 & 0.0437 \\
LNACG & -1.538091 & 0.9564 & -6.107167 & 0.9313 \\
LNFDI & -4.515025 & 0.0564 & 9.945054 & 1.0000
\end{tabular}

Source: Authors' Computation using E-views 9.0, 2019.

The result of table 6 shows that there is a long run relationship between all the variables (LSP, TGE, ACG, FDI) in model 2 . This is because there is evidence of two variables being significant at $5 \%$ and $10 \%$ significance levels. These are TGE with 0.0437 probability value at z-statistics and FDI with 0.0564 at tau-statistics. Arising from this, it is evident that there is a long run relationship among the variables, since there is evidence of two co-integrating equations in t-statistics and in z-statistics respectively. 
INTERNATIONAL JOURNAL OF ACADEMIC RESEARCH IN BUSINESS AND SOCIAL SCIENCES Vol. 10, No. 1, Jan, 2020, E-ISSN: 2222-6990 @ 2020 HRMARS

Table 7: Engle-Granger Single Equation Co-integration Test Result for Model 3

\begin{tabular}{lllll} 
Variables & \multicolumn{2}{l}{ tau-statistic Prob. ${ }^{*}$} & z-statistic & Prob. $^{*}$ \\
\hline LNFRP & -0.564091 & 0.9967 & -1.865129 & 0.9962 \\
LNTGE & -1.709825 & 0.9332 & -5.708664 & 0.9437 \\
LNACG & -1.752546 & 0.0260 & -6.905264 & 0.9017 \\
LNFDI & -4.153528 & 0.0889 & -20.81816 & 0.1214 \\
\hline \hline
\end{tabular}

Source: Author's Computation using E-views 9.0.

Based on the table above, it is evident that there is a long run relationship between all the variables involved in this model, that is, FRP, TGE, ACG, FDI, with the result showing that two variables are significant at $1 \%$ and $10 \%$ significance levels. They are ACG with 0.0260 probability value at taustatistics and FDI with 0.0889 at tau-statistics. This means that there is a long run relationship among the variables, since there is evidence of two co-integrating equations in t-statistics.

Table 8: Engle-Granger Single Equation Co-integration Test Result for Model 4

\begin{tabular}{|c|c|c|c|c|}
\hline \multirow{2}{*}{$\frac{\text { Variables }}{\text { LNFSP }}$} & \multicolumn{2}{|c|}{ tau-Statistic Prob.* } & \multirow[t]{2}{*}{ z-Statistic } & \multirow[t]{2}{*}{ Prob.* } \\
\hline & & & & \\
\hline LNTGE & -1.734624 & 0.8354 & -5.739824 & 0.8447 \\
\hline LNACG & -2.626720 & 0.4430 & -8.280465 & 0.0662 \\
\hline LNFDI & -4.579446 & 0.0208 & 9.295322 & 1.0000 \\
\hline
\end{tabular}

Source; Author's Computation using E-views 9.0

Table 8 reveals an evidence that there is a long run relationship between all the variables involved in this model i.e. InTGE, InACG, InFDI, with the result showing that there are two variables that are significant at $5 \%$ and $10 \%$ significance level, which are InFDI with 0.0208 probability value at taustatistics and InACG with 0.0662 at z-statistics. This means there is a long run relationship among the variables since there is evidence of two co-integrating equation in t-statistics and z-statistics.

\section{Discussion of Findings}

By streamlining the analyses on the four separate sub-sectors of the agricultural sector - crop production (CRP), livestock production (LSP), forestry production (FRP) and fish production (FSP); consequently, the results of the study are accordingly discussed. The results of the study reveal that TGE and AGS have a positive relationship with crop production, while FDI has a negative relationship with CRP. The R-Squared $\left(R^{2}\right)$ has a value of 0.970733 (approximately, 97.0733\%). Also, the result of the t-statistics shows that TGE and ACG are statistically significant; while FDI is not. Our results are in line with the reports of Akintola (2004), Ayoola and Oboh (2006) who used autocorrelation estimation in conducting a study on the role of banking industry in financing agricultural activities in Nigeria. The results have shown that for crop production to perform well, then availability of adequate capital is not just a necessary condition but a sufficient one. Also, Rhaji (2008) lending support to our study argues that the systemic decline in the contributions of agriculture to Nigerian economy is due to the lack of adequate, accessible and affordable credit for the sector. The effectiveness of any agricultural 
INTERNATIONAL JOURNAL OF ACADEMIC RESEARCH IN BUSINESS AND SOCIAL SCIENCES Vol. 10, No. 1, Jan, 2020, E-ISSN: 2222-6990 @ 2020 HRMARS

credit program depends not only on its availability, accessibility and affordability, but also on its proper and efficient allocation and utilization for intended uses by beneficiaries (Oboh, 2008).

The results of livestock model also reveal that AGS and TGE have a positive relationship with LSP, while FDI has a negative relationship with LSP. The R-Squared $\left(R^{2}\right)$ has a value of 0.933220 (approximately 93.32\%). The result of the t-statistics shows that ACG is statistically significant in the model, while TGE and FDI are not statistically significant. In relation with this, Ubah (2009) documents that agricultural credit asserts positive impact on agricultural output in Nigeria. In assessing the factors that determine the performance of the Nigerian agricultural sector, Oboh and Ekpebu (2010) present an argument that funding-based contribution is the most impacting and critical determinant of the performance of the Nigerian agricultural sector; availability of formal credit (Ammaini, 2012); Deposit Money Banks loans and advances (Imoisi, Sogules \& Ekpeyoung, 2012); and institutional credit supply (Onoja, 2012) are documented as well.

On the account of FRP, it is revealed that TGE and FDI have a negative relationship with FRP, while AGS has a positive relationship with forestry. The R-Squared $\left(R^{2}\right)$ has a value of 0.841942 (approximately $84.19 \%$ ). Also, the result of the t-statistics shows that ACG and FDI are statistically significant, while TGE is not. FDI as the amount of international inflows of funds into a country shows a negative relationship with the agriculture performance. This implicitly means that the FDI over the years has been diverted to other sectors of the economy and the little invested in the Nigerian agricultural sector has not been used judiciously; thereby resulting to its negative impact on agriculture performance in the country. In line with the results of our study, Nwankwo (2013) reports a significant relationship between agricultural financing and the growth of Nigerian agricultural outputs. Enyim, Ewno and Okoro (2013) applying co-integration technique reports that banking sector credit is a panacea to the problems of the Nigerian poor performance. Obilor (2013) who studied the impact of agricultural credit scheme fund, agricultural product prices, government fund allocation and commercial banks' credit to agricultural sector on agricultural productivity, says that ACG and government expenditures produce a significant positive effect on agricultural productivity; and Ibe (2014) accepts that public sector financing activities make impressive significant impact on agricultural output in Nigeria.

The results of the fourth model show that TGE and AGS have a positive relationship with FSP, while FDI is found to be negatively related with FSP. The R-Squared $\left(R^{2}\right)$ shows a value of 0.905008 (approximately 90.50\%); meanwhile, the result of the t-statistics shows that ACG and TGE are significant in the model because their probability values are less than the level of significance (5\%), despite the fact that FDI is not significant. By lending support to this finding, Nnamocha and Eke (2015) employing error correction mechanism alluded to the fact that bank credit, as a source of funding-based contribution, significantly impacts on agricultural output in Nigeria. Agunuwa, Inaya and Proso (2015) carried out a study to examine the impact of commercial banks' credits on fishing agricultural productivity in Nigeria. The findings from the study show that there is a positive relationship between commercial banks' credit and fishing agricultural productivity; however, a negative relationship between interest rate and fishing agricultural productivity and a significant 
INTERNATIONAL JOURNAL OF ACADEMIC RESEARCH IN BUSINESS AND SOCIAL SCIENCES

Vol. 10, No. 1, Jan, 2020, E-ISSN: 2222-6990 @ 2020 HRMARS

positive relationship between government spending and fishing agricultural productivity in Nigeria. Okolo, (2004) confirmed that commercial banks' credit significantly and positively impacts on fishing agricultural output in Nigeria; and Olowofeso, Adeboye, Adejo, Bassey and Abraham (2017) argued in favour of credit having significant impact on fishing output growth in the agricultural sector of Nigeria.

\section{Concluding Remarks and Recommendations for Policy Actions}

On the ground of assessing the performance of the Nigerian agricultural sector, this paper empirically sought to establish if there is, or otherwise, a long run relationship between agricultural fundingbased contributions and performance of the Nigerian agricultural sector from 1986 to 2018. While certain diagnostic tests were conducted to determine normality in the distribution of data of the variables, ADF unit root test was equally done to ascertain stationarilty and order of integration of the variables. Fully modified ordinary least square (FMOLS) was employed to test for the short run impact of agricultural funding-based contributions on performance of Nigerian agricultural sector; and the establishment of the long run impact was done using Engle-Granger Single Equation cointegration test for the four equations. The performance of the Nigerian agricultural sector was done by decomposing the contributions of four components of the sector into crop production, livestock production, forestry production and fishing production; whereas agricultural funding-based contributions are inferentially identified and used as total government expenditure, agricultural credit guarantee scheme fund and foreign direct investment to agriculture.

The novelty of this study hinges on the fact that it is the first, to the best of our knowledge - as evidenced in the extant literature, to assess the relationship between agricultural funding-based contributions and the performance of agricultural sector in Nigeria, from 1986 to 2018, using a collection of four diagnostic tests tools namely; Jarque-Bera; Breush-Godfrey; Breush Pagan Godfrey; and Ramsey reset. The study also makes a combination of Fully Modified Ordinary Least Square (FMOLS) estimation technique and Granger Single Equation Co-integration Test. Theoretically, the study confirms the potency of financial intermediation and Wagner's theories; as TGE is found to be positively related with CRP, LSP and FSP, expect for FRP. More importantly, from the analyses of the study, the findings of the study are summarized as follows: TGE and AGS have a positive relationship with CRP and LSP, while FDI has a negative relationship with CRP and LSP; TGE and FDI have a negative relationship with FRP, while AGS has a positive relationship with FRP; and TGE and AGS have a positive relationship with FSP, while FDI is found to be negatively related with FSP. From the result, it is evident that there is a long run relationship between all the variables used in the CRP, LSP equations. This is because the analyses of the models have results showing that there is at least one variable is significant at $5 \%$ significance level; which is the InFDI having 0.0182 probability value at tau-statistics; InTGE has 0.0437 probability value at z-statistics and InFDI having 0.0564 at tau-statistics; InACG has 0.0260 probability value at tau-statistics and InFDI has 0.0889 at tau-statistics respectively. The study concludes that various estimation results above show there is an actual relationship between agricultural fund-based contributions and the performance of the Nigerian agricultural sector within the period of study. Also, it is instructive to report that among the independent variable, ACG proves a pivotal position in the nation's agricultural sector because of its positive contributions to the various 
sub-sectors in agricultural sector. To improve the aggregate impact of ACG on the economy, the government needs to widen the coverage of the credit by reasonably extending it to farmers in the remote and rural areas.

Empirical evidence in the paper supports research effort to distil impacting and pragmatic policy messages on the basis of some general prepositions. In order to increase the agricultural performance in Nigeria, government should adopt measures and strategies to redirect its expenditure on the agricultural sector by using selective credit control measures in order to persuade banks to grant more loans and advances to agricultural sub sector. This will enable the agricultural firms have the needed financial resources to expand production and thereby increase total output. Also, government should strengthen agricultural credit guarantee scheme and more institutions in order to monitor and grants more credits to agricultural sector in Nigeria and increase its total expenditure to the agricultural sector. An increment in government expenditure should be encouraged so as to contribute to the country's agricultural sector which will in turn lead to an overall boom in the nation's productivity. This follows the proposition that if more funds are channelled to agriculture it will surely yield multiple positive effects on aggregate national output by confirming a theoretical implication that financial intermediation promotes economic growth.

\section{References}

Agunuwa, E. V., Inaya, L., \& Proso, T. (2015). Impact of commercial banks' credit on agricultural productivity in Nigeria (time series analysis 1980 - 2013). International Journal of Academic Research in Business and Social Sciences, 5(11), 151-163.

Akintola, S. (2004). Banks move against Soludo. Nigerian Tribune (July 23rd), p.24.

Ammani, A. A. (2012). An investigation into the relationship between agricultural production and formal credit supply in Nigeria. International Journal of Agriculture and Forestry, 2(1), 46-52.

Ariff, N. Z. Z. M., Kassim, N. A., Shoid, M. S. M., Abdullah, C. Z., Baharuddin, K., Mansor, M. H. M. @, ... Radzi, R. (2018). The Benefits of Using Social Media and the Impact of not filtering the Information. International Journal of Academic Research in Progressive Education and Development, 7(3), 304-313.

Ayeomoni, O. I., \& Aladejana, S. A. (2016). Agricultural credit and economic growth nexus evidence from Nigeria. International Journal of Academic Research in Accounting, Finance and Management Sciences, 6(2), 146-158.

Ayoola, G. B., \& Oboh, V. U. (2006). A model of public expenditure to reveal the preference for agriculture in the budget. Journal of Rural Economic Development, 14 (1), 56-73.

Baffoe, G., Matsuda, H., Nagao, M., \& Akiyama, T. (2014). The dynamics of rural credit and its impact on agricultural productivity: An empirical study in rural Ghana. International Journal of Sustainable Development, 7(5), 19-34.

Bhilawa, L., Kautsar, A. (2018). The Determinants of Relationship Between Budgetary Participation and Budgetary Slack, International Journal of Academic Research in Accounting, Finance and Management Sciences 8 (2): 155-163. 
INTERNATIONAL JOURNAL OF ACADEMIC RESEARCH IN BUSINESS AND SOCIAL SCIENCES

Vol. 10, No. 1, Jan, 2020, E-ISSN: 2222-6990 @ 2020 HRMARS

Caroline, S. (2019). Sustainable agriculture - life beyond subsidies: Lessons from new Zealand. Journal of Agricultural Economics, 70(3), 579 - 594. https://doi.org/10.1111/14779552.12354.

Chisasa, J., \& Makina, D. (2013). Bank credit and agricultural output in South Africa: A Cobb-Douglas empirical analysis. International Business and Economics Research Journal, 12(4), 387-398.

Colman, D., \& Young, T. (1989). Principles of agricultural economics: markets and prices in less developed countries. Cambridge: Cambridge University Press.

Edewor, S. E., Dipeolu, A. O., Ashaolu, O. F., Akinbode, S. O., Ogbe, A. O., Edewor, A. O., Tolorunju, E. T. \& Oladeji, S. O. (2018). Contribution of foreign direct investment and other selected variables to agricultural productivity in Nigeria: 1990-2016. Nigerian Journal of Agricultural Economics, 8(1), October. Handle: RePEc: ags: naaenj:280320. DOI: 10.22004/ag.econ.280320.

Enyim, O. B., Ewno, E. N., \& Okoro, O. T. (2013). Banking sector credit and the performance of the agricultural sector in Nigeria. European Journal of Scientific Research, 23(2), 35-55.

Faluyi, K. (1996). The development of agricultural exports and official intervention in produce marketing in G. O. Ogunremi and E.K. Faluyi (Eds). An economic history of West Africa since 1750. Ibadan: Rex Charles Publication.

Ibe, S. O. (2014). The impact of banks' and public sector's financing activities on agricultural output in Nigeria. Journal of Agriculture and Environmental Sciences, 3(2), 129-143.

IFAD. (2001). International Fund for Agricultural Development.

Iheanacho, E. (2016). The contribution of government expenditure on economic growth of Nigeria disaggregated approach. International Journal of Economics and Management Sciences, 5(5), 369. doi: 10.4172/2162-6359.1000369

Imoisi, A. I., Sogules, I. W., \& Ekpeyoung, B. I. (2012). An appraisal of credit facilities on agricultural output and productivity in Nigeria, 1970-2010. British Journal of Humanities and Social Sciences, 7 (2), $56-75$.

Greenwood, J. \& Jovanovic, B. (1990). Financial development, growth and the distribution of income. Journal of Political Economy, 98(5), 1076-1107.

https://corporatefinanceinstitute.com/resources/knowledge/finance/pecking-order-theory/

Mallum, A. (2016). A review of agricultural finance policy development in Nigeria. Annals of Borno, 26, 167-171.

Nnamocha, P. N., \& Eke, C. N. (2015). Bank credit and agricultural output in Nigeria (1970-2013): An error correction model (ECM) approach. British Journal of Economics, Management \& Trade, 10(2), 1-12.

Nwankwo, O. (2013). Agricultural financing in Nigeria: An empirical study of Nigerian agricultural cooperative and rural development bank (NACRDB): 1990-2010. Journal of Management Research, 5(2), 28-44.

Obilor, S. I. (2013). The impact of commercial banks' credit to agriculture on agricultural development in Nigeria: An econometric analysis. International Journal of Business Humanities and Technology, 3(1), 85-95. 
Oboh, V. U. (2008). Farmer's allocative behaviour in credit utilization: a case study of arable crop farmers in Benue State, Nigeria. A Ph.D Dissertation, Agricultural Economics and Extension Programme, Abubakar Tafawa Balewa University, Bauchi, Nigeria.

Oboh, V. U. \& Ekpebu, I. D. (2011). Determinants of formal agricultural credit allocation to the farm sector by arable crop farmers in Benue State, Nigeria. African Journal of Research, 6 (1), 181185.

Ogbuabor, J. E. \& Nwosu, C. A. (2017). The impact of deposit money bank's agricultural credit on agricultural productivity in Nigeria: Evidence from an error correction model. International Journal of Economics and Financial Issues, 7(2), 513-517.

Oji-Okoro, I. (2011). Analysis of the contribution of agricultural sector on the Nigerian economic development. World Review of Business Research, 1(1), 191-200.

Okolo, D. A. (2004). Regional study on agricultural support: Nigeria's case. Special Study Report prepared for Food and Agricultural Organization (FAO).

Olomola, A. S. (1997). Agricultural finance. In A.O Phillips and S.T. Titilola (eds.) Nigeria in 2010. Ibadan: NISER, 51-62.

Olowofeso, O. E., Adeboye, A. A., Adejo, V. T., Bassey, K. J. \& Abraham, O. (2017). Agricultural sector credit and output relationship in Nigeria: Evidence from nonlinear ARDL. CBN Journal of Applied Statistics, 8(1), 101-122.

Onoja, A. O., Onu, M. E. \& Ajodo-Ohiemi, S. (2012). Contributions of financial sector reforms and credit supply to Nigerian agricultural sector (1978-2009).

Oparinde, L. O., Amos, T. T. \& Adeseluka, M. (2017). Influence of agricultural credit guarantee scheme fund (ACGSF) on fishing development in Nigeria. Scientific Papers Series Management, Economic Engineering in Agriculture and Rural Development, 17(1), 157 - 193.

Papapavlou, A., \& Satraki, M. (2013). Language of advertising in bidialectal settings: Does the code matter? Multilingual Academic Journal of Education and Social Sciences, 1(2), 1-14.

Schumpeter, J. A. (1934). The theory of economic development. Cambridge, MA: Harvard University Press.

Ubah, C. C. (2009). Impact of agricultural credit on agricultural output in Nigeria. Unpublished M.Sc. Thesis. Department of Economics, Nnamdi Azikiwe University, Awka.

Udeorah, S. F., \& Vincent, M. O. (2018). Agriculture financing and performance of the agricultural sector in Nigeria, 1981-2015. International Journal of Research in Computer Application \& Management, 8(1).

Udoka, C. O., Mbat, D. O. \& Duke, S. B. (2016). The effect of commercial banks' credit on agricultural production in Nigeria. Journal of Finance and Accounting, 2016, 4(1), 1-10.

Papapavlou, A., \& Satraki, M. (2013). Language of advertising in bidialectal settings: Does the code matter? Multilingual Academic Journal of Education and Social Sciences, 1(2), 1-14.

Uzomba, P. C., Peter Chika Uzomba, T. N., \& Otokutu, O. P. (2020). Agricultural Funding-Based Contributions and Performance of Nigerian Agricultural Sector. International Journal of Academic Research in Business and Social Sciences, 10(1), 300-318. 